Riwayat Artikel: Diterima 15 Juni 2017; Direvisi 14 Juli 2017; Disetujui 18 Juli 2017; dan Dipublikasikan 26 Juli 2017

\title{
PEMANFAATAN SITUS WEB RESMI LEMBAGA PENDIDIKAN SEBAGAI SUMBER BERITA OLEH WARTAWAN SURAT KABAR LOKAL DI YOGYAKARTA
}

\section{THE USAGE OF EDUCATIONAL ORGANIZATION OFFICIAL WEBSITE AS NEWS SOURCES BY LOCAL NEWSPAPER'S JOURNALISTS IN YOGYAKARTA}

\author{
Narayana Mahendra Prastya \\ (narayana@uii.ac.id)
}

(Program Studi Ilmu Komunikasi, Fakultas Psikologi dan Ilmu Sosial Budaya, UII)

\begin{abstract}
Abstrak
Penelitian ini berangkat dari pemikiran bahwa media berbasis internet dapat memudahkan organisasi dalam melakukan hubungan dengan media dengan memfasilitasi kemudahan berbagi informasi. Lembaga pendidikan dipilih sebagai batasan, karena hubungan media merupakan aktivitas yang cukup penting bagi lembaga tersebut. Penelitian ini menggunakan metode deskriptif kualitatif, dengan teknik pengumpulan data berupa wawancara dengan pihak redaksi media. Narasumber penelitian adalah perwakilan dari redaksi surat kabar lokal di Yogyakarta. Hasil penelitian menunjukkan bahwa narasumber mempercayai situsweb resmi organisasi pendidikan sebagai sumber informasi untuk mengembangkan berita, atau sebagai alternatif ketika kekurangan berita. Informan mengkritik kualitas informasi dan cara penyajian informasi yang terdapat di situsweb resmi yang masih belum memenuhi kebutuhan wartawan.
\end{abstract}

Kata Kunci: Hubungan Media, Internet Public Relations, Sumber Berita, Website Resmi

Abstract

This resarch based on concept that stated internet give organization advantages in media relations activities. Educational institution being chosen because media relations is important for them. This research uses descriptive qualitative method. The data-collecting technique is interview. The informant of the interview is representative from newsroom local newspapers in Yogyakarta. The research result shows that informant give their trust to official website from educational organization. Informant use the information to explore the issue and/or as alternative when they face condition lack of news. Informant also criticize the information quality and the structure of information that published on official website.

Keywords: Media Relations, Cyber Public Relations, News Sources, Official Website

\section{Pendahuluan}

Terdapat hubungan yang saling membutuhkan antara sebuah organisasi dengan media. Organisasi memerlukan media untuk menyampaikan informasi kepada masyarakat; sebaliknya media membutuhkan organisasi sebagai bahan berita. Itu sebabnya, organisasi perlu melakukan hubungan media yang baik. Menurut Averill, hubungan media dapat menjadi perangkat yang sangat penting dan efisien bagi eksistensi organisasi. Begitu organisasi bisa menyusun pesan yang bukan saja diterima, tetapi juga dipandang penting oleh media, maka

organisasi sudah membuat langkah besar menuju keberhasilan programnya (dalam Iriantara, 2005: 28). Manfaat hubungan media bagi organisasi tidak hanya sebatas publikasi. Menurut Setyanto dan Anggarina (2015: 223), hubungan media dapat menjadi sarana bagi organisasi untuk mendekatkan diri dengan masyarakat.

Aktivitas hubungan media juga merupakan hal yang penting bagi lembaga pendidikan. Bagi lembaga penyelenggara pendidikan (sekolah, perguruan tinggi) misalnya, hubungan yang baik dengan media dapat meningkatkan citra lembaga 
tersebut di masyarakat. Hubungan media yang baik akan membuat penelitianpenelitian, pemikiran-pemikiran dari civitas akademika diberitakan oleh media. Itu membuat masyarakat menjadi tahu bagaimana kualitas dari lembaga pendidikan tersebut. Bagi lembaga pendidikan yang berperan sebagai pengambil keputusan (misalkan direktorat, badan pemerintah), hubungan media yang baik dapat memudahkan untuk penyampaian kebijakan kepada masyarakat.

Secara umum ada berbagai aktivitas dalam hubungan media, salah satunya berbagi informasi antara organisasi dengan media. Umumnya, organisasi melakukan kegiatan berbagi informasi melalui event maupun tulisan. Dalam bentuk event misalnya, dengan mengundang wartawan untuk menghadiri konferensi pers (baik itu yang berlangsung rutin/terjadwal atau memang dilakukan khusus berkaitan dengan isu tertentu), media briefing, dan media tour. Sedangkan dalam bentuk tulisan dilakukan dengan mengirimkan siaran pers kepada media (Dewi, 2012).

Kehadiran media berbasis internet dapat membantu organisasi dalam aktivitas berbagi informasi dengan media, khususnya dalam bentuk tulisan. Situsweb dan akun sosial media resmi organisasi, hingga layanan percakapan personal (chat) memungkinkan organisasi untuk segera menyampaikan informasi kepada wartawan, tanpa harus bertemu langsung secara fisik. Internet, menurut Dewa Broto (2014: 40), memungkinkan organisasi menyampaikan informasi kepada wartawan dengan cara yang cepat dan terbuka.

Pada berbagai media berbasis internet tadi, tulisan ini akan fokus kepada situsweb resmi organisasi (official website) guna menunjang kegiatan hubungan media. Situsweb merupakan media komunikasi online yang memuat beragam informasi berkaitan dengan organisasi, untuk diketahui publik. Salah satu publik dari organisasi adalah media/wartawan. Itu sebabnya, situsweb dapat digunakan sebagai sumber informasi bagi para pekerja media untuk mengetahui lebih jauh mengenai organisasi (Dewi, 2012: 25-26).

Melalui situsweb resmi, organisasi dapat memberikan penjelasan secara detil mengenai berbagai hal. Situsweb resmi memungkinkan organisasi untuk memberikan penjelasan secara langsung, dan dapat meminimalkan terjadinya kesalahan pemberitaan oleh media. Pasalnya publik bisa langsung mengetahui bagaimana sebenarnya penjelasan organisasi, dengan melihat pernyataan yang disampaikan melalui situsweb resmi. Bagi redaksi media, situsweb resmi organisasi dapat memberikan keuntungan yakni menghemat waktu. Wartawan tidak perlu setiap saat datang langsung ke organisasi untuk melakukan liputan.

Secara konseptual, situsweb resmi dapat memudahkan wartawan dalam pencarian berita. Namun bagaimana pada prakteknya? Tulisan ini hendak melihat bagaimana wartawan memanfaatkan situsweb resmi organisasi sebagai sumber informasi dalam memproduksi berita. Tujuannya adalah untuk menilai apakah situsweb resmi sudah cukup membantu wartawan dalam proses pencarian informasi, dan apakah sudah cukup sesuai dengan kebutuhan wartawan.

Batasan dalam penelitian ini adalah situsweb resmi dari organisasi perguruan tinggi. Alasan memilih organisasi perguruan tinggi adalah, bagi perguruan tinggi situsweb resmi merupakan salah satu hal yang penting dan harus dikelola secara serius. Salah satu bukti dari kualitas perguruan tinggi adalah adanya pemeringkatan Webometrics yang melihat pada performa situsweb perguruan tinggi.

Penelitian ini merupakan penelitian deskriptif kualitatif. Teknik pengumpulan data dalam penelitian adalah wawancara. Ada pun informan penelitian adalah perwakilan redaksi surat kabar lokal di kawasan Yogyakarta. Yang dimaksud 
dengan perwakilan redaksi adalah pemimpin redaksi, redaktur rubrik pendidikan dan/atau reporter rubrik pendidikan.

Pemilihan Yogyakarta sebagai objek penelitian ini karena kawasan ini menjadi tujuan untuk menempuh pendidikan. Perguruan tinggi di Yogyakarta dipandang menawarkan biaya yang relatif lebih murah dibanding kota lain. Mahasiswa pun punya kesempatan untuk melanjutkan kuliah ke jenjang berikutnya dengan banyaknya beasiswa yang ditawarkan (Meodia, 2015). Dengan kondisi tersebut, maka media lokal menjadi partner penting bagi lembaga pendidikan untuk bisa meraih peserta didik.

Sementara itu, peneliti merangkum tiga jenis tema penelitian, yakni (1) membahas pemanfaatan situsweb resmi oleh lembaga pendidikan; (2) menganalisis hubungan media yang dilakukan oleh lembaga pendidikan dari sudut pandang wartawan; dan (3) standar nilai berita pendidikan menurut media massa.

\begin{tabular}{llr}
\multicolumn{2}{c}{ Lembaga pendidikan seperti } \\
perguruan tinggi dan sekolah
\end{tabular} memanfaatkan situsweb resmi sebagai sarana menyampaikan informasi kepada publik, sebagai media yang membantu publik untuk mencari informasi, untuk menunjang aktivitas hubungan media, sebagai saluran untuk mengklarifikasi opini publik atau pemberitaan yang beredar, dan sebagai media untuk mendokumentasikan berbagai aktivitas perguruan tinggi, membangun image positif, promosi, dan branding. Situsweb resmi memberikan keuntungan di antaranya berbiaya lebih murah dan memiliki cakupan yang lebih luas (Dewi dan Prastya, 2015). Namun kendala dalam pengelolaan situsweb resmi lembaga pendidikan adalah pada faktor Sumber Daya Manusia. Minimnya jumlah personel serta kemampuan yang dimiliki membuat pemanfaatan situsweb resmi menjadi kurang maksimal. Alhasil, dari segi kualitas isi informasi dan data masih kurang baik (Ekawati, 2010; Utari, 2013).

Dari sudut pandang wartawan, masih ada sejumlah kekurangan dalam aktivitas hubungan media di perguruan tinggi. Misalkan perguruan tinggi dianggap menjaga jarak dan bahkan tertutup terhadap media--khususnya ketika tengah ada masalah. Padahal media berharap perguruan tinggi lebih mudah dijangkau dan lebih ramah dengan media. Hubungan yang terjadi tidak hanya saat konferensi pers atau hal yang bersifat prestatif (Nurjanah dkk., 2015; Setyanto dan Anggarina, 2015).

Terdapat dua faktor, yakni kedekatan dan keunikan, yang menjadi pertimbangan media dalam memberitakan peristiwa seputar dunia pendidikan. Faktor kedekatan dipilih berdasarkan target pembacanya. Faktor keunikan yang dimiliki oleh lembaga pendidikan -- baik dari segi akademik atau non-akademik-dipilih agar pembaca memiliki referensi dalam memilih lembaga pendidikan yang seusai dengan kebutuhan (Wulan, 2015).

Namun begitu, dalam penelitian lain menyebutkan fakta bahwa wartawan berpendapat bahwa perguruan tinggi kurang aktif dalam menyebarkan informasi yang menarik, seperti hasil-hasil riset, temuan ilmiah, dan pengembangan akademik. Namun sayangnya perguruan tinggi tidak mampu mengelola informasi, sehingga informasi-informasi yang disampaikan kepada wartawan hanya halhal yang sifatnya kurang penting seperti wisuda dan kunjungan (Nurjanah dkk., 2015; Setyanto dan Anggarina, 2015).

Kerangka Pemikiran: Media Berbasis Internet guna Menunjang Aktivitas Hubungan Media

Sejak lama perkembangan teknologi secara umum telah mempengeruhi praktek PR. Teknologi informasi telah secara dramatis mengubah cara PR dalam distribusi informasi, berinteraksi dengan publik-publik penting, berhadapan dengan krisis, dan manajemen isu. Saat ini, 
perkembangan teknologi komunikasi yang ditandai dengan lahirnya situsweb, internet, dan media digital lainnya dipandang telah mengubah banyak hal dalam PR (Lindic, 2006; Pavlik, 2008).

Salah satu media komunikasi yang paling efektif yang dapat digunakan oleh praktisi Public Relations dalam menyampaikan informasi tentang perusahaan tempat PR itu berada adalah situsweb (Darmastuti, 2012; Ekawati, 2010), sebagai saluran komunikasi antara organisasi dengan publik. Situsweb dapat digunakan public relations dalam melakukan program-program komunikasi, di antaranya hubungan dengan media (Grunig, 2009). Sebuah studi menunjukkan bahwa hubungan yang kuat antara organisasi dengan publiknya dapat dibangun melalui situsweb (Idris, 2010). Melalui situsweb, organisasi dapat menyampaikan hal yang hendak mereka sampaikan, menjaga informasi informasi yang positif dan mencegah informasi negatif (Dewa Broto, 2014).

Salah satu public dalam organisasi adalah media. Salah satu publik dari organisasi adalah media/wartawan. Itu sebabnya, situsweb dapat digunakan sebagai sumber informasi bagi para pekerja media untuk mengetahui lebih jauh mengenai organisasi. Terlebih lagi apabila pekerja media membutuhkan informasi secara cepat. Situsweb resmi memungkinkan organisasi untuk berkomunikasi dengan media secara lebih efektif dan efisien dan menjadi sarana untuk mengklarifikasi informasi yang salah (Dewa Broto, 2014; Dewi, 2012).

Bagaimana gambaran umum pemanfaatan situsweb resmi organisasi oleh wartawan? Dari penelusuran literature hingga naskah ini dikirimkan, penulis masih belum menemukan penelitian berkaitan dengna hal tersebut. Penulis mencoba menarik simpulan awal dari penelitian mengenai pemanfaatan media sosial oleh wartawan (Dewan Pers, 2012). Konteks media sosial di sini adalah media yang memungkinkan berbagi informasi, interaktif, komunikasi dua arah, dan tidak terbatas pada media sosial resmi organisasi.

Dalam survey yang dilakukan oleh Dewan Pers terhadap 157 wartawan di Indonesia menunjukkan tingkat penggunaan media sosial guna menunjang aktivitas bekerja wartawan di Indonesia menunjukkan angka yang cukup tinggi, yakni 76 persen menggunakan media sosial sebagai sarana memantau informasi, 46 persen sebagai sumber ide berita, dan 24 persen sebagai bahan berita. Responden survey ini adalah 157 orang wartawan 157 responden yang tersebar di 21 kota di Indonesia (Dewan Pers, 2012).

Mayoritas responden (75 persen) menyatakan melakukan verifikasi ulang untuk seluruh informasi yang ada di media sosial (Dewan Pers, 2012). Hal ini merupakan keniscayaan, karena media sosial adalah media yang: 'tidak bisa dengan mudah dikendalikan' (Pridmore et.al., 2013: 2), dalam artian informasiinformasi yang bertebaran di media sosial sangatlah beragam, mulai dari yang benar hingga berita bohong yang memang sengaja disebarkan untuk memicu kepanikan.

Jika media sosial - dengan kelemahannya tersebut - cukup sering menjadi rujukan bagi wartawan sebagai sumber informasi, maka penulis mengasumsikan bahwa situsweb resmi organisasi dapat lebih sering digunakan sebagai sumber informasi oleh wartawan. Pasalnya, informasi yang ada di situsweb resmi sudah pasti valid. Situsweb resmi sulit dipalsukan, dan sudah jelas pengelolanya.

Namun begitu situsweb juga memiliki kelemahan. Aliran informasi dari situsweb bersifat satu arah. Ini membuat situsweb dipandang terlalu kaku, formal, eksklusif, jarang diperbarui, hanya menyerupai laporan tahunan, berisi statistik, dan muluk muluk, sehingga informasi yang ada tidak layak untuk 
dipublikasikan -menurut standard pers (Idris, 2010; Iriantara, 2005).

Kelemahan tersebut terjadi lebih karena faktor pemahaman praktisi PR terhadap piranti media berbasis internet. Media berbasis internet tak pelak menuntut praktek baru dalam cara-cara kerja PR (Grunig, 2009; Macnamara, 2010), namun akibat kurangnya pemahaman, praktisi PR masih menjalankan cara-cara tradisional PR dalam berkomunikasi dengan publiknya (James, 2007; Macnamara, 2010).

\section{Metodologi}

Penelitian ini menggunakan metode kualitatif. Sifat penelitian adalah deskriptif. Data dalam penelitian ini diperoleh dengan cara melakukan wawancara. Penentuan narasumber wawancara dalam penelitian ini dilakukan dengan cara purposive sampling, yakni pemilihan narasumber berdasarkan karakteristik tertentu yang dianggap memiliki hubungan dengan penelitian ini. Narasumber penelitian adalah perwakilan dari redaksi media cetak di Yogyakarta, untuk memperoleh informasi mengenai proses produksi berita khususnya di rubric/desk pendidikan, informasi atau peristiwa berkaitan dengan pendidikan yang dipandang memiliki nilai berita, dan berita-berita apa saja dari situsweb perguruan tinggi yang kemudian menjadi sumber informasi. .

Pada tahap awal penelitian, penulis mengajukan surat permohonan izin untuk melakukan wawancara ke empat redaksi media cetak di Yogyakarta, yakni Kedaulatan Rakyat, Harian Bernas, Tribun Jogja, dan Harian Jogja. Pemilihan keempat media cetak tersebut berdasarkan pertimbangan bahwa mereka memiliki rubrik mengenai pendidikan.

Dari empat permohonan tersebut, tiga surat kabar yakni Kedaulatan Rakyat, Harian Bernas, dan Harian Jogja menyatakan kesediaan untuk diwawancarai. Sementara redaksi Tribun
Jogja, menyatakan tidak bersedia untuk diteliti karena satu dan lain hal. Hal tersebut disampaikan melalui surat elektronik oleh HRGA Manager PT Media Tribun Yogya, Maharani K. Negara (surat elektronik diterima penulis pada 16 Agustus 2016).

Wawancara dilakukan terhadap pemimpin redaksi dan/atau redaktur rubrik yang bertanggungjawab terhadap beritaberita pendidikan. Terdapat lima narasumber, yakni sebagai berikut:

1. Riyana Ekawati (jabatan: Redaktur Rubrik Pendidikan Harian Kedaulatan Rakyat), tanggal wawancara: 31 Mei 2016. 2. Anton Wahyu Prihantono (jabatan: Pemimpin Redaksi Harian Jogja), tanggal wawancara: 1 Juni 2016.

3. Nugroho Nurcahyo (jabatan: Redaktur Rubrik Humaniora di Harian Jogja), tanggal wawancara: 1 Juni 2016.

4. Putut Wiryawan (jabatan: Pemimpin Redaksi Harian Bernas), tanggal wawancara: 31 Agustus 2016.

5. Warjono (jabatan: Redaktur Rubrik Pendidikan Harian Bernas), tanggal wawancara: 6 September dan 9 September 2016.

Wawancara berlangsung secara tatap muka, di kantor redaksi masing-masing media. Dalam wawancara, peneliti menggunakan media alat rekam audio dan buku catatan. Khusus untuk wawancara dengan Warjono (narasumber nomor 5) dilakukan melalui surat elektronik atas permintaan narasumber. Teknisnya, peneliti mengirimkan daftar pertanyaan melalui surat elektronik ke narasumber, dan narasumber membalas dengan mengirimkan jawaban.

\section{Hasil dan Pembahasan}

Para narasumber yang diwawancarai mengakui bahwa rutin mengunjungi situsweb resmi lembaga pendidikan baik itu berupa kampus atau lembaga pemerintah yang bertanggungjawab dalam mengelola pendidikan. Narasumber mengatakan bahwa informasi yang dicari 
di situsweb resmi lembaga pendidikan adalah seputar seminar, prestasi civitas akademika, inovasi, pengabdian masyarakat, agenda lembaga pendidikan, keputusan atau kebijakan baru, dan lainlain. Informasi-informasi yang ada di situsweb resmi tersebut kemudian dikembangkan untuk menjadi bahan liputan. Hal tersebut terdapat dalam petikan wawancara dengan Nugroho Nurcahyo (Harian Jogja) dan Riyana Ekawati (Kedaulatan Rakyat) berikut:

"Kebetulan saya selalu buka setiap hari. Info seputar kampus, seperti ada seminarapa yang bagus, sudah di pubish atau belum. Informasi tim humas itu sudah cukup untuk jadi berita, dan kami tulis di tulisan kami yang diambil dari laman resmi UGM semisal. Yang masih kami rasa kurang mendalam nanti saya bisa minta wartawan untuk menemui langsung. Jadi info yang dikeluarkan dari kampus menjadi informasi awal kami sebelum kami terjun ke lapangan" (Nugroho Nurcahyo, Harian Jogja).

"Termasuk saya sendiri juga sering memanfaatkan. Tetapi lebih sering kepada website pusat. Terlebih itu adalah isu nasional, yang mungkin nantinya kita kembangkan di isu daerah. Setiap hari mereka (reporter-pen) rutin ngecek website. Kalau menarik dan bagus bermanfaat untuk masyarakat umum biasanya mereka (reporter-pen) ngambil. Semisal datanya cukup, harus tetap diedit. Takutnya (jika tidak diedit-pen) nanti sama dengan media lain” (Riyana Ekawati, Kedaulatan Rakyat).

Pihak media menilai situsweb resmi dapat memberikan informasi yang valid. Hal tersbut terdapat dalam petikan wawancara dengan Putut Wiryawan (Bernas) berikut:

"Kalau bagi saya itu (situsweb lembaga pendidikan-pen) positif.
Karena website perguruan tinggi itu resmi. Saat kita mencari referensi menulis sesuatu, kita akan mencari juga ke portal-portal tertentu. Tentu bagi Bernas, lebih mempercayai portal perguruan tinggi daripada blog-blog yang sifatnya umum" (Putut Wiryawan, Bernas).

Situsweb resmi dimanfaatkan sebagai sumber informasi awal bagi sebuah berita. Semua narasumber menyatakan bahwa setelah memperoleh informasi dari situsweb resmi lembaga pendidikan, reporter tetap harus melakukan liputan ke narasumber langsung. Jika mengutip informasi dari situsweb resmi, maka media memiliki standar kerja harus menuliskan sumbernya.

Pihak media merasa terbantu dengan adanya situsweb resmi. Menurut narasumber Nugroho Nurcahyo (Harian Jogja), informasi yang ada dalam situsweb resmi relatif lebih mudah dipahami dibandingkan dengan siaran pers. Pasalnya informasi dalam siaran pers kadang terlalu panjang dan banyak memuat hal-hal yang dirasa kurang penting.

"Dilihat dari segi konten saya lebih nyaman yang website karena mereka biasanya sudah mennghadirkan dalam format seperti berita begitu. Kalau press release, ya mereka seperti proposal penelitian. Yang jelas apa yang mau disampaikan itu tidak jelas. Dengan beberapa pendahuluan yang kami pikir tidak perlu" (Nugroho Nurcahyo, Harian Jogja).

Situsweb resmi lembaga pendidikan juga dimanfaatkan saat keadaan "darurat", maksudnya adalah ketika redaksi media dihadapkan pada situasi kekurangan berita menjelang deadline. Itu pun situsweb resmi lembaga pendidikan menjadi alternatif terakhir. Pasalnya media juga berlangganan dari kantor berita lain, atau mengambil informasi dari media yang menjadi jaringan dari media tersebut. Hal tersebut terdapat dalam petikan wawancara 
dengan Warjono (Bernas) dan Anton Wahyu Prihantoro (Harian Jogja) sebagai berikut:

"Saya mengutip tulisan atau informasi dari website resmi, hanya ketika kekurangan bahan berita. Ketika materi berita dari wartawan mencukupi, saya melihat informasi atau berita sekadar sebagai bahan masukan untuk pengembangan lebih lanjut melalui wartawan" (Warjono, Bernas).

"Ketika kita memang membutuhkan hal itu dimuat di website organisasi itu memang menjadi alternatif terakhir bagi kami. Karena kami mengutamakan berita liputan tementemen (wartawan-pen) dulu...Baru kemudian berita yang dari langganan kami, ANTARA atau detik.com...atau jaringan kami yang ada seperti Solo Pos dan Bisnis Indonesia. Bagaimana dengan berita-berita yang ditampilkan oleh website universitas itu? Nah itu nanti kadang memang kami mengutip namun ada yang kami kemudian menambahi. Kita memang mengupayakan misalnya kita wawancara sedikit, kemudian sisanya mengutip website. Atau alternatif terakhir, kita mengutip website nanti ditambah beberapa kata-kata tambahan" (Anton Wahyu P, Harian Jogja).

Secara konseptual, situsweb resmi organisasi idealnya dapat memudahkan tugas baik bagi organisasi dan juga wartawan. Keberadaan situsweb memungkinkan organisasi memberikan penjelasan dengan segera; sementara dengan memanfaatkan situsweb resmi organisasi wartawan dapat memperoleh akses informasi yang bersifat cepat dan terbuka. Namun segala keunggulan situsweb tersebut akan menjadi sia-sia apabila tidak disertai dengan isi dan tampilan yang menarik (Dewa Broto, 2014; Dewi, 2012).
Lalu bagaimana penilaian narasumber terhadap situsweb lembaga pendidikan? Dari segi isi, semua narasumber berpandangan bahwa materi/tema yang dipublikasikan kurang memiliki nilai berita. Materi yang terdapat di situsweb lembaga pendidikan (dalam hal ini perguruan tinggi) masih terlalu dominan pada hal-hal yang bersifat sermonial atau pun kepentingan internal kampus seperti persemian gedung, penandatanganan kerjasama, dan sejenisnya. Bagi wartawan, informasiinformasi seperti ini kurang penting bagi khalayak. Narasumber mengatakan bahwa pihaknya belum memperoleh cukup materi dari situsweb resmi perguruan tinggi yang berisi tentang analisis dari pakar di bidangnya. Hal tersebut terdapat dalam petikan wawancara dengan Riyana Ekawati (Kedaulatan Rakyat) berikut

"Hampir semua belum ada. Misalnya ini pakar lingkungan hidup, pakar hukum ini, nanti dia ngomong apa disitu, itu belum ada. Jadi kita masih kebingungan, itu mungkin juga perlu” (Riyana Ekawati, Kedaulatan Rakyat).

Narasumber lain mengatakan bahwa media sebenarnya membutuhkan hal-hal yang unik.Namun, sejauh ini situsweb resmi perguruan tinggi lebih banyak membahas tentang seremonial atau penyelenggaraan seminar ilmiah. Hal tersebut terdapat dalam petikan wawancara dengan Nugroho Nurcahyo (Harian Jogja) berikut:

"Bagi kami informasi tentang seminar sebenarnya nomor dua. Seminar kan cuma melulu ngomongin tumpahan ide semua, wacana....Karya mahasiswa, karya inovatif itu menurut kami lebih menarik daripada paparan wacana. Karena untuk wacana kita masih bisa menampilkan itu di kolom opini Yang utama bagi kami adalah yang unik, dari hal yang tidak pernah 
disangka oleh public" (Nugroho Nurcahyo, Harian Jogja).

Keunikan merupakan salah satu kriteria dalam menentukan nilai berita (Wulan, 2015). Belum adanya kesamaan persepsi antara lembaga pendidikan dengan media tentang informasi yang menarik bagi publik, menjadi salah satu penyebab mengapa informasi yang ada di situsweb resmi menjadi alternatif terakhir bagi media. Keunikan, menurut wartawan desk pendidikan adalah hal-hal yang berkaitan dengan karya mahasiswa atau hasil-hasil inovasi yang bermanfaat bagi masyarakat namun belum banyak diketahui. Hal tersebut terdapat dalam petikan wawancara dengan Anton Wahyu Prihantoro (Harian Jogja) sebagai berikut: "Mungkin perspektifnya berbeda ada sesuatu yang mungkin menurut pandangan kami sangat menarik, tapi menurut mereka biasa saja. Contoh pernah dengar orang menjadi donor nyamuk dengan darahnya sendiri? Itu ada di UGM, sudah beberapa tahun berjalan tapi tidak ter-publish. Jadi setiap hari kami di situ (liputan di UGM-pen), ada tangan dari pegawai di pusat penelitian yang dimasukan dimasukan kantong yang berisi nyamuk kemudian itu untuk memberi makan nyamuk. Itu untuk penelitian dalam rangka penelitian demam berdarah. Dan itu katanya kalau Anda mau menurunkan kolesterol itu silahkan. Nah, hal-halitu yang tidak pernah tahu" (Anton Wahyu P, Harian Jogja).

Narasumber lain yakni Putut Wiryawan (Bernas) berpandangan bahwa kemasan informasi yang disediakan oleh pihak perguruan tinggi masih terlalu datar. Ia mencontohkan dalam informasi tentang ujian disertasi/doktoral, perguruan tinggi hanya menyediakan informasi tentang siapa nama orang yang menjalani ujian, siapa nama promotornya, kemudian ringkasan dari hasil penelitian, dan bagaimana status kelulusannya. Menurut Putut, dari segi kelengkapan informasi memang sudah lengkap. Tetapi informasi tersebut kurang menarik. Sebaiknya ada informasi-informasi yang sifatnya lebih humanis, seperti proses ujian, sehingga pembaca bisa merasa lebih 'terlibat' dengan keadaan yang terjadi. Selengkapnya sebagai berikut

"Yang sifatnya human, misalya kalau kandidat doktor ini menjawab dengan cerdas beberapa pertanyaan, nah atau mungkin tidak bisa menjawab pertanyaan itu kan suasana di dalam proses ujian itu. Dari cara pandang media, masyarakat itu kan membutuhkan suasana yah dalam berita itu, sehingga tahu, secara emosional jadi terlibat di dalam informasi dari media ke masyarakat" (Putut Wiryawan, Bernas).

Selain dari segi informasi berita, narasumber juga menilai struktur informasi yang ada masih belum memenuhi kaidah penulisan jurnalistik. Hal tersebut menyulitkan pihak wartawan untuk memahami informasi. Meskipun sudah memenuhi unsur-unsur kelengkapan berita, namun susunan informasi yang belum sesuai harapan menjadi keluhan wartawan. Hal tersebut dapat dilihat dalam petikan wawancara dengan Warjono (Bernas) dan Riyana Ekawati (Kedaulatan Rakyat) sebagai berikut

"Menurut saya, sebagian besar isi/informasi yang ada di website sudah memenuhi nilai berita. Tapi baru sebagian kecil yang disajikan dengan teknis penulisan yang baik secara jurnalistik. Baru sebagian kecil website resmi perguruan tinggi yang tersaji cukup apik. Baik dari aspek penulisan informasi/berita, ataupun dari aspek daya tarik sebuah informasi” (Warjono, Bernas).

"Ada juga yang, jujur, baca leadnya saja sudah bingung. Kadang 
masih struktur katanya saja sudah bikin bingung, agak berantakan gitu ya. Seharusnya informasi ditaruh di bawah itu tetapi ditaruh di atas. Kan rancu, jadi terkadang terbolak balik gitu. Jadi tulisannya belum bisa dikatakan bagus. Mungkin sudah memenuhi $5 \mathrm{~W} 1 \mathrm{H}$, tetapi belum bagus. Jadi masih perlu penyuntingan bahasa. Karena bahasa jurnalistik kan juga berbeda dengan bahasa humas (Riyana Ekawati, Kedaulatan Rakyat).

Berkaitan dengan hal teknis, narasumber secara umum mengatakan tidak menemui kendala yang berarti. Beberapa masalah dikemukakan narasumber seperti situsweb resmi terlalu berat ketika diakses melalui telepon pintar, atau tidak ada flash untuk menampilkan visual bergerak, dipandang bukan sebagai masalah besar. Narasumber lebih menyoroti kepada faktor konten dari situsweb resmi. Narasumber mengharapkan informasi-informasi yang ada di situsweb resmi lembaga pendidikan dapat diperbarui secara rutin, dengan ada setidaknya empat hingga lima informasi baru di setiap harinya. Tentu saja, tidak hanya dari segi kuantitas tetapi juga diharapkan informasi-informasi terbaru tersebut juga memiliki nilai berita yang menarik untuk dipublikasikan.

Sementara itu, situsweb memang memiliki berbagai kelebihan, sehingga dengan kelebihan tersebut situsweb resmi organisasi diharapkan dapat menjadi media pertukaran informasi yang bermanfaat bagi organisasi dengan media (Darmastuti, 2012; Dewa Broto, 2014; Dewi, 2012; Ekawati, 2010).

Temuan penelitian ini menunjukkan bahwa sebenarnya ada salah satu publik dari organisasi--yakni media--yang memanfaatkan situsweb resmi organisasi sebagai sumber informasi. Pihak media mengaku lebih nyaman menggunakan situsweb resmi karena informasinya lebih ringkas, tidak bertele-tele dibandingkan siaran pers.

Temuan ini sejalan dengan pemikiran yang menyatakan bahwa melalui situsweb, organisasi dapat menyampaikan hal yang hendak mereka sampaikan, menjaga informasi informasi yang positif dan mencegah informasi negatif. Situsweb resmi memungkinkan organisasi untuk berkomunikasi dengan media secara lebih efektif dan efisien, terlebih dalam situasi di mana wartawan membutuhkan informasi secara cepat (Dewa Broto, 2014; Dewi, 2012).

Ada dua motif penggunaan informasi di situsweb resmi organisasi. Pertama adalah sebagai bahan untuk mengembangkan berita. Namun begitu, dari pihak organisasi dinilai masih memiliki sejumlah kekurangan sehingga pemanfaatan situsweb resmi organsiasi sebagai (salah satu) sarana komunikasi dengan publik menjadi tak maksimal.

Dari pemaparan narasumber, informasi yang ada di situsweb masih kurang baik dari segi kualitas informasi atau pun cara penyajian informasi. Dari segi kualitas informasi, fakta-fakta yang dipublikasikan di situsweb resmi masih belum memenuhi kriteria nilai berita. Fakta-fakta yang dipublikasikan cenderung seremonial, hanya ide dan wacana, dan terlalu berfokus pada kepentingan internal organisasi. Temuan ini senada dengan penelitian sebelumnya (lihat Setyanto dan Anggarina, 2015; Wulan, 2015). Jadi, dalam hal ini tampaknya terdapat kecenderungan umum bahwa perguruan tinggi belum memahami informasiinformasi apa yang sebaiknya dipublikasikan kepada masyarakat.

Mayoritas narasumber dalam informasi yang dipublikasikan di situsweb resmi perguruan tinggi adalah jajaran pimpinan perguruan tinggi - misalkan rektor, wakil rektor, dekan, wakil dekan, dan pejabat struktural lainnya. Dalam satu informasi, bisa terdapat lebih dari satu narasumber. Misalkan narasumber dari 
kalangan yang mewakili kajian dari disiplin ilmu dan dari pimpinan struktural perguruan tinggi. Namun begitu, presentase dari kalangan keilmuan tetap kalah banyak dibandingkan dengan pimpinan struktural. Ini menunjukkan bahwa situsweb resmi perguruan tinggi masih terkesan 'elit' (Dewi dan Prastya, 2015).

Pemilihan tema publikasi yang terkesan 'elit' ternyata membuat informasi yang ada menjadi tidak menarik, karena tema tersebut tidak sesuai dengan kebutuhan wartawan, yang dengan kata lain juga belum sesuai dengan kebutuhan publik. Pemilihan informasi yang terlalu banyak kandungan kepentingan internal, pemilihan narasumber yang terlalu dominan pejabat struktural, menunjukkan pemahaman organisasi bahwa mereka masih bisa mengontrol informasi, di mana yang layak, yang pantas untuk menjadi sumber informasi hanya dari kalangan elite atau orang-orang penting lembaga pendidikan saja.

Padahal informasi yang seperti itu ternyata kurang menarik bagi media, karena tidak memenuhi nilai berita. Dalam temuan penelitian, narasumber mengungkapkan keinginan mereka akan informasi-informasi yang unik, seperti inovasi mahasiswa, prestasi mahasiswa, atau kisah human interest dari civitas akademika kampus.

Dari segi cara penyampaian informasi, narasumber juga mengaku masih kebingungan. Pasalna, informasi yang dipublikasikan di situsweb resmi belum sesuai standar $5 \mathrm{~W}+1 \mathrm{H}$. Itu menyebabkan narasumber harus bekerja lagi untuk mengolah informasi yang ada.

Hal ini menjadikan narasumber hanya menggunakan informasi yang ada di situsweb resmi sebagai alternatif terakhir apabila menjelang batas waktu (deadline) masih kekurangan berita. Ini sekaligus merupakan motif kedua penggunaan situsweb resmi oleh wartawan. Ini berarti, informasi yang ada hanya bersifat sebagai pelengkap atau pengisi space kosong di halaman surat kabar nantinya.

Penelitian ini menyimpulkan bahwa situsweb resmi lembaga pendidikan situsweb resmi sudah digunakan organisasi untuk aktivitas hubungan media (Grunig, 2009). Wartawan pun percaya situsweb resmi organisasi merupakan sumber yang valid. Namun, wartawan masih belum terlalu memanfaatkannya sebagai sumber berita. Bukan karena wartawan tersebut enggan, tetapi lebih karena situsweb resmi belum mampu memenuhi kebutuhan wartawan. Itu artinya, efektifitas situsweb resmi sebgai media untuk menyampaikan informasi (Darmastuti, 2012; Ekawati, 2010), masih belum terbukti berdasarkan penelitian ini. Kekurangan-kekurangan tersebut sekaligus mengonfirmasi pendapat yang menyatakan bahwa kekurangan situsweb resmi adalah bahasa yang terlalu kaku, informasi yang cenderung eksklusif, sehingga membuat isinya menjadi kurang menarik, sehingga informasi yang ada tidak layak untuk dipublikasikan -menurut standard pers (Idris, 2010; Iriantara, 2005).

Kekurangan-kekurangan dalam performa situsweb resmi yang terungkap dari hasil penelitian ini, juga dapat dipandang sebagai belum siapnya humas atau pengelola situsweb resmi organisaasi dalam memanfaatkan internet (Grunig, 2009; James, 2007; Macnamara, 2010). Padahal, untuk mengoptimalkan media berbasis internet, humas perlu memiliki strategi baru dan cara kerja baru (Pavlik, 2008).

\section{Penutup}

Wartawan telah memanfaatkan situsweb resmi lembaga pendidikan sebagai salah satu sumber informasi. Informasi yang ada di situsweb resmi digunakan sebagai bahan untuk mengembangkan berita atau sebagai alternatif terakhir jika masih kekurangan berita di surat kabar. Narasumber penelitian ini mengatakan bahwa mengutip dari situsweb resmi memungkinkan, tetapi 
pada prinsipnya mereka lebih mementingkan melakukan konfirmasi ulang atau mengembangkan informasi yang diperoleh dari situsweb resmi dengan cara mewawancarai narasumber. Apabila terpaksa harus mengutip, maka wartawan menuliskan ulang dengan bahasa yang dirangkai sendiri.

Situsweb resmi secara konseptual dapat menawarkan kemudahan bagi organisasi untuk menjalin hubungan dengan media. Tetapi faktanya, pihak wartawan menilai masih ada kekurangan dari situsweb resmi organisasi. Kekurangan itu terletak pada aspek materi/isi informasi yang masih kurang memperhatikan nilai-nilai berita; dan cara penyampaian informasi di mana struktur kalimat serta penyusunan informasi yang masih belum rapi sehingga membingungkan wartawan.

Penelitian ini memiliki sejumlah keterbatasan, yakni: (1) objek penelitian hanya terbatas media cetak lokal yang ada di Yogyakarta, (2) narasumber yang diwawancarai sebagian besar adalah pihak pengambil keputusan (pemimpin redaksi, redaktur) di masing-masing media, (3) tema situsweb resmi adalah spesifik di bidang pendidikan.

Untuk penelitian selanjutnya peneliti memberikan saran, misalkan pemanfaatan situsweb resmi sebagai sumber berita oleh reporter, wartawan yang bertugas di lapangan. Asumsinya adalah wartawan yang bertugas di lapangan wajib untuk memantau informasi secara lebih intens dibandingkan dengan redaktur atau pemimpin redaksi yang ada di kantor.

Penelitian lain adalah pemanfaatan situsweb resmi oleh wartawan di bidang yang memiliki tuntutan berita lebih cepat dibanding bidang pendidikan, seperti misalkan bidang politik, olahraga, dan sebagainya. Penelitian juga dapat diperluas dengan pemanfaatan akun-akun media sosial resmi organisasi (Twitter, Facebook, dan sebagainya) sebagai sumber berita oleh wartawan.
Penelitian selanjutnya juga dapat mengambil tema pemanfaatan media berbasis internet resmi yang dikelola organisasi oleh publik yang berbeda, seperti misalkan konsumen, masyarakat umum, dan sebagainya. Apabila penelitian ini menjadikan pengguna (user) dari situsweb resmi sebagai subjek yang diteliti, maka penelitian selanjutnya juga dapat membahas dari produsen pesan yakni humas (atau unit kerja lain yang menjadi penanggungjawab), misal bagaimana mereka melakukan penyesuaian terhadap strategi dan pola kerja dalam menggunakan media berbasis internet dalam aktivitas komunikasi organisasi.

\section{Daftar Pustaka}

Darmastuti, R. (2012). Media Relations (Konsep, Strategi dan Aplikasi). Yogyakarta: Penerbit ANDI.

Dewa Broto, G. S. (2014). The PR: Tantangan Public Relations di Era Keterbukaan Informasi. Jakarta: Gramedia Pustaka Utama.

Idris, I. K. (2010). Manajemen Blog Korporat dalam Membentuk Citra Perusahaan: Studi Kasus Blog Perusahaan Jasa Konsultan PR Maverick Indonesia www.maverickid.com. Dalam Diyah Hayu Rahmitasari (Ed.), Potret Manajemen Media di Indonesia. Yogyakarta: Prodi Ilmu Komunikasi UII dan Penerbit Buku Litera.

Iriantara, Y. (2005). Media Relations (Konsep, Pendekatan dan Praktik). Bandung: Simbiosa Rekatama Media.

Setyanto, Y. \& Anggarina, P. T. (2015). Humas pada Perguruan Tinggi Hubungan dengan Media pada Institusi Pendidikan. Dalam Aswad Ihsak (Ed.), Komunikasi dan Isu Publik. Yogyakarta: ASPIKOM, Unika Widya Mandala Surabaya, Univ. Kristen Petra Surabaya, Univ. 
Muhammadiyah Malang, dan Penerbit Buku Litera.

Dewi, M. (2012). Media Relations 2.0. Jurnal Komunikasi, 7 (2), 17-28.

Dewi, M. dan Prastya, N. M. (2015). Pemanfaatan Website sebagai Sarana Branding Perguruan Tinggi: Studi terhadap Website Resmi Universitas Islam Indonesia (www.uii.ac.id). Proceeding Conference on Communication, Media, and Sociology 2015: Imagining eIndonesia: Local Wisdom in the Midst of Media Technology and Communciation Policy (297-308). Yogyakarta: Universitas Atma Jaya.

Ekawati, R. (2010). Pemanfaatan Website oleh Kehumasan (Studi Kasus Universitas Negeri Yogyakarta). Tesis Tidak Dipublikasikan. Yogyakarta: Pascasarjana Ilmu Komunikasi, Fakultas Ilmu Sosial dan Ilmu Politik, Universitas Gadjah Mada.

Grunig, J. (2009). Paradigms of Global Public Relations in an Age of Digitalisation. PRism, 6 (2), 1-19.

James, M. (2007). A Review of The Impact of New Media on Public Relations: Challenges for Terrain, Practice, and Education. Asia Pacific Public Relations Journal, 8, 137148.

Lindic, J. (2006). How do Corporations Use Internet for Public Relations. BLED Proceedings Paper, 7, 1-8.

Macnamara, J. (2010). Public Communication Practices in The Web 2.0-3.0 Mediascape: The Case for PRevolution. PRism, 7(3), 1-13.
Nurjanah, A., Widyasari, W. \& Yulianti, F. (2015). Wartawan dan Budaya Amplop (Budaya Amplop pada Wartawan Pendidikan dalam Kaitannya dengan Media Relations). Jurnal Informasi, 45 (1), 15-24.

Pridmore, J., Falk, A., \& Sprenkels, I. (2013). New Media \& Social Media: What's The Difference? Working Paper for use in: CM $2550 \mathrm{New}$ Media and International Business Departement of Media and Communiation. Erasmus University.

Utari, R. (2013). Website sebagai Media Humas Sekolah. Jurnal Penelitian Ilmu Pendidikan, 6 (2), 78-87.

Wulan, S. (2015). Memahami Kebijakan Redaksional Rubrik Pendidikan di Surat Kabar Harian Solopos. Jurnal The Messenger, 7 (2), 18-25.

Dewan Pers. (2012). Interaksi Jurnalis dengan Media Sosial. URL: http://dewanpers.or.id/opini/detail/6 5/interaksi-jurnalis-dengan-mediasosial, diakses 12 September 2016.

Meodia, A. (21 Agustus 2015). Yogyakarta, kota Tujuan para Pendatang Indonesia. www.antaranews.com.

Pavlik, J. V. (2008). Mapping the Consequences of Technology on Public Relations. Diakses pada 14 Juli 2012, URL: http://www.instituteforpr.org/topics/ mapping-technology-consequences/. 